\title{
Aneta Skalec
}

Uniwersytet Warszawski

\section{OCHRONA ŚWIATŁA I WIDOKU W PRAWIE RZYMSKIM I TRAKTACIE URBANISTYCZNYM JULIANA Z ASKALONU}

W miastach basenu Morza Śródziemnomorskiego już od czasów Grecji klasycznej były tworzone prawa związane z budownictwem czy szerzej wyglądem miast (Stela z portu na Tazos z V w. p.n.e ${ }^{1}$. i tekst z Pireusu z IV w. p.n.e.), dotyczące także w pewnym zakresie stosunków między sąsiadami. Regulacje $\mathrm{z}$ tego zakresu powstawały także w okresie hellenistycznym (np. Podręcznik z Hermopolis ${ }^{2}$, pochodzący z III w. p.n.e. czy Prawo Astynomów z Pergamonu z z III-II w. p.n.e.) i rzymskim.

Najdłuższym i najbardziej szczegółowym znanym nam antycznym tekstem dotyczącym budownictwa prywatnego jest Traktat Urbanistyczny Juliana z Askalonu, napisany gdzieś pod koniec V lub w VI w. n.e. przez architekta Juliana pochodzącego z Askalonu. Zebrał on w nim prawa i zwyczaje obowiązujące w Palestynie w zakresie wznoszenia i odnawiania budynków, różnych ich elementów (np. balkonów) czy lokalizowania innych instalacji (np. latryny czy kana-

${ }^{1}$ H. Duchene, La Stèle du Port. Fouilles du Port 1. Recherches sur une nouvelle inscription thasienne, Athenes 1992.

${ }^{2}$ G. Mattha, The demotic legal code of Hermopolis West, Cairo 1975.

3 OGIS II 483. 
lizacja $)^{4}$. Traktat ten składa się z krótkiego wstępu, w którym autor przedstawił przedmiot swojej pracy (rozwiązywanie konfliktów między sąsiadami i zapobieganie szkodom, jakie mogły być wywołane w najbliższym sąsiedztwie w wyniku różnego rodzaju działań) oraz dwóch części. Pierwsza zawiera szereg dyspozycji o charakterze technicznym i podzielona jest na podrozdziały, których organizacja oparta jest o cztery żywioły: Dział I (§ 3-15) - Ogień. W tej części autor reguluje odległości pomiędzy budynkami a różnego rodzaju warsztatami, których działalność mogła powodować szkody, wynikające z użycia ognia, emitowania dymu, ciepła itp.; Dział II (§16-39) - Powietrze. Jest najbardziej zróżnicowany i zawiera dyspozycje dotyczące m.in. odległości pomiędzy budynkami, wysokości na jakich mogą być wybite okna, wznoszenia balkonów; Dział III (§ 40-46) - Woda. Zawiera dyspozycje dotyczące lokalizowania latryn, kanałów ściekowych itp.; Dział IV (§ 47-51) - Ziemia. Zawiera dyspozycje dotyczące kopania rowów czy sadzenia roślin. Druga część (§ 52-56), znacznie krótsza, zawiera szczegółowe regulacje dotyczące ochrony widoku na morze, góry, ogród i malowidła publiczne.

W prawie rzymskim wznoszenia i funkcjonowania budynków prywatnych dotyczyły przede wszystkim służebności, ale poświęcony był im także cały jeden tytuł 8,10-De aedificiis privatis (O budynkach prywatnych) Kodeksu Justyniana. Najważniejszą z zawartych w nim konstytucji jest C. 8,10,12 cesarza Zenona skierowana do praefectus urbis Konstantynopola Adamanzia nawiązująca do wcześniejszego aktu cesarza Leona, który nie zachowała się do naszych czasów. Co wyjątkowe i bardzo charakterystyczne dla niej napisana była ona po grecku. Dlatego też nie znajdujemy jej w zachodnich manuskryptach Kodeksu Justyniana zawierających jedynie łacińskie konstytucje. Jej tekst zachował się natomiast razem z Nowelami Justyniana i Leona Mądrego w Marcianus 179. Dopiero od edycji Kodeksu Justyniana dokonanej przez Constiusa (1559-62) została ona włączona do tytułu de

\footnotetext{
${ }^{4}$ C. SAliou, Le traité d'urbanisme de Julien d'Ascalon, Paris 1996, s. 1-28.
} 
aedificiis privatis ${ }^{5}$. Współcześni badacze zajmujący się tą konstytucją przyjmują zazwyczaj, że mamy tu do czynienia z oryginalnym tekstem Zenona, na co wskazuje zarówno pełna tytulatura cesarska, która w Kodeksie Justyniana była zawsze zredukowana do tytułu Imperatora, jak i dygresje o charakterze historycznym i geograficznym ${ }^{6}$. Nie znamy dokładnej daty jej wydania z powodu braku subscriptio. Cesarz Zenon panował w latach 474-491 n.e., ale konstytucja najprawdopodobniej została wydana w latach 474-477, kiedy to prefektem miasta był wymieniony w niej Adamanzio. Możliwe, iż została ona wydana po pożarze, który strawił dużą część Konstantynopola w 475 r. n.e. i mogła być odpowiedzią na zniszczenia przez niego wywołane ${ }^{7}$. Najprawdopodobniej jej zasięg początkowo był ograniczony tylko do stolicy $^{8}$, ale Justynian rozszerzył zakres jej obowiązywania w $531 \mathrm{r}$. n.e. na teren całego imperium 9 .

Ważnymi zagadnieniami poruszanym zarówno w prawie rzymskim jak i traktacie Juliana była ochrona światła i widoku i te zagadnienia ze względu na podobieństwo ich uregulowania w obu źródłach, będą przedmiotem niniejszego artykułu.

W prawie rzymskim ochrony widoku dotyczyła grupa służebności określanych zbiorczą nazwą iura luminum, do których należały: ius altius tollendi aut non tellendi, ius ne luminibus officiatur oraz servitus luminum $^{10}$.

5 V. CAPOCCI, Nota per la storia del testo della costituzione $\pi \varepsilon p \grave{~ \kappa} \alpha \mathrm{\imath vo \tau o \mu} \mu \mathrm{\imath} \omega$ dell'imp. Zenone, «SDHI» 7/1941, s. 158-70.

${ }^{6}$ B. Biondi, La L. 12 Cod. de Aed. Priv. 8, 10 e la questione delle relazioni legislative tra le due parti dell'impero, «BIDR»44/1936-37, s. 370; V. CAPOCCI, op. cit., s. 157.

7 L. Minieri, Un ,altro” caso di normativa antiincendio in diritto romano postclassico, «Diritto e Storia. Rivista Internazionale di Scienze Giuridiche e Tradizione Romana. In Memoria di Feliciano Serrao» 5/2006, z http://www.dirittoestoria.it/5/ Memorie/Minieri-Normativa-anticendio-diritto-romano.htm.

${ }^{8}$ V. CAPOCCI, op. cit., s. 179.

9 C. $8,10,13$.

${ }^{10}$ S. SolazzI, Requisiti e modi di costituzione delle servitù prediali, Napoli 1947, s. $62-6$. 
Servitus altius non tollendi zakazywała właścicielowi gruntu służebnego podwyższenie wysokości budynku ponad określone granice. Jej przeciwieństwem była servitus altius tollendi pozwalająca właśnie na podwyższenie budynku także w sytuacji, gdy ograniczało to dostęp światła do sąsiedniego budynku ${ }^{11}$. Nieco podobna do altius non tollendi była servitus ne luminibus officiatur ${ }^{12}$, a więc służebność nieograniczania światła. Było to prawo do posiadania okien lub otworów doświetlających niezacienianych z sasiedniego terenu. Nie do końca jest jasne czy były to dwie osobne służebności, czy też jedna servitus altius non tollendi ne luminibus officiatur. Jako jedną zdaje się traktować je cały szereg fragmentów w Digestach ${ }^{13}$ a także Gajus ${ }^{14}$. Ale są także i takie teksty, które wskazują na ich oddzielnośćc ${ }^{15}$. Traktują one niekiedy tę drugą służebność jako ochronę przed posadzeniem drzewa mogącego ograniczyć doświetlenie pomieszczenia, a w przypadku posadzenia szpaleru drzew w ogóle całego budynku ${ }^{16}$. Możliwe więc, że były to jednak dwie osobne służebności, gdzie altius non tollendi miała zapewnić światło budynkowi zakazując zwiększania jego wysokości, a ne luminibus officiaturi chronić przed jakimkolwiek innym ograniczaniem dostępu światła do domu ${ }^{17}$.

Poza tym prawu rzymskiemu znane były jeszcze dwie służebności związana ze światłem - servitus luminum ${ }^{18}$, czyli służebność światła oraz servitus luminis imittendi ${ }^{19}$. Pierwsza $\mathrm{z}$ nich polegała na prawie wybicia lub posiadania okna lub innego otworu w ścianie należącej do innej osoby lub będącej przedmiotem współwłasności w celu za-

\footnotetext{
${ }^{11}$ C. $3,34,8$; C. $3,34,9$.

12 D. $8,2,4$; I. $2,3,4$.

${ }^{13}$ D. $8,2,6$; D. $8,4,16$; D. 8,3,2 pr.; D. 8,2,1; D. 7,1,13,7.

${ }^{14}$ G. $2,3,1$.

15 D. $8,2,17$ pr.; D. $17,2,52$.

16 D. $8,2,4$.

17 S. Solazzi, op. cit,. s. 78.

18 D. $8,2,4$.

19 D. $8,2,40$.
} 
pewnienia dostępu światła do własnego budynku ${ }^{20}$. Natomiast servitus luminis imittend $i^{21}$ oznaczała prawo wybicia okna wychodzącego na cudzy teren. Powodowała ona jednocześnie konieczność znoszenia takiego stanu rzeczy przez sąsiada, który nie mógł żądać likwidacji otworów. Zapobiegała ona także wznoszeniu budynku przy ścianie sąsiada, przez co ograniczała swobodę właściciela gruntu służebnego w budowaniu domu ${ }^{22}$.

Nie znamy konkretnych sytuacji, w których ta ostatnia służebność znajdowała zastosowanie. Wydaje się jednak, że służebność analogiczna lub podobna do servitus luminis imittendi występowała dosyć często na Bliskim Wschodzie, na co mogą wskazywać zarówno źródła literackie $^{23}$ jak i postanowienia zawarte w traktacie Juliana:

$\S 28$. 1. Jeśli zaś ściana ma od dawna okna „strzelnicze” i dom nie ma żadnego innego okna doświatlającego i okno „strzelnicze” ma od dziesięciu lat, w takim wypadku chcący wybudować nowy dom musi oddalić się od ściany o 3 i 1/3 łokcia.

Prawo do nieblokowania światła powstawało więc, zgodnie z tym co dowiadujemy się z traktatu Juliana, automatycznie z upływem dziesięciu lat o ile okna wybite w ścianie stanowiły jedyne źródło światła. Powodowało ono niemożność wzniesienia przez sąsiada budynku przylegającego do wcześniej istniejącego, zmuszając go do pozostawienia pustego pasa ziemi, przy czym właściciel gruntu władnącego nie uzyskiwał w ten sposób oczywiście żadnego prawa do tej wolnej przestrzeni ${ }^{24}$.

W regulacji z zakresu ochrony światła widoczny jest w traktacie silny związek między zapewnieniem światła a odprowadzaniem wody, jako elementami bezpośredniego sąsiedztwa. Paragrafy poświęco-

${ }^{20}$ C. SAliou, Les lois des bâtiments. Voisinage et habitat urbain dans l'Empire Romain. Recherches sur les rapports entre le droit et la construction privée du siècle d'Auguste au siècle de Justinien, Beyrouth 1994, s. 224.

21 D. $8,2,40$.

22 S. SolazZI, op. cit., s. 80-90.

23 C. Saliou, op. cit., s. 227.

${ }^{24}$ C. SAliou, Le traité d'urbanisme de Julien d'Ascalon, § 39,3. 
ne oknom poprzedzają bezpośrednio te o odprowadzaniu wody ${ }^{25}$. W § 39 dotyczącym odległości wymaganej w przypadku lokalizacji rynien przewidziane było, że regulacje te miały zastosowanie także do okien. Taki związek między światłem i odprowadzaniem wody widoczny jest także w Liber syro-romanus ${ }^{26}$ i w prawie rzymskim, gdzie przejawia się on w podobieństwie między servitus stillicidii i servitus luminis imittendi ${ }^{27}$.

W ścisłym związku ze światłem pozostawał także widok. To właśnie ze służebności chroniących światło rozwinęła się w prawie rzymskim specjalna służebność chroniąca widok - ius ne prospectui officia$t u r^{28}$, zakazująca ograniczania widoku jaki dana osoba miała ze swojego domu. Oczywiście niemożliwe było w miastach takie wznoszenie domów, aby nigdy i w żaden sposób nie ograniczały one widoku na określone obiekty, w związku z czym potrzebne były w tym zakresie stosowne regulacje.

Różnego rodzaju niedogodności mogły wynikać także z faktu bliskiego sąsiedztwa domów i wychodzenia ich okien na siebie. Mogło to powodować ingerencję w prywatność sąsiadów, być źródłem sprzeczek itp. Zasadniczo nie mogło stanowić to jednak przeszkody do wzniesienia budynku, co dobrze obrazuje jeden z paragrafów zawartych w traktacie Juliana:

§ 55. 1. Niektórzy, będąc złośliwymi i zawistnymi, starają się uniemożliwić budowania domów wznoszonych w taki sposób, że w przyszłości będą miały widok na sąsiadów.

2. Zaś ani prawa nie wspominają, ani na przykładzie starych domów nie widzimy, żeby starsi myśleli, że jest to niesprawiedliwe. Widzimy bowiem, że wszystkie domy z bliska patrzą jedne na drugie i że starożytni sądzili, że żaden zawistny (człowiek) nie może powstrzymywać tego. Stąd i my nie uważamy, żeby patrzenie było krzywdą.

\footnotetext{
25 Tamże, § 27, 28 o oknach i 29 o rynnach.

$26 \S 120$ (FIRA II 795).

${ }^{27}$ C. SAliou, Les lois des bâtiments cit., s. 227.

${ }^{28}$ D. $8,2,3$; D. 8,2,15.
} 
3. Każdy więc kto sądzi, że stanowi to krzywdę będzie musiał pozwolić zbudować (budynek), zaś sam zamknie dom i będzie strzegł się przed patrzeniem bądź przez zasłanianie otworów okiennicami, bądź zasłonami lub jak kto chce.

Generalnie zatem fakt, iż mający powstać budynek sąsiadował z innym, na który miał widok nie mogło stanowić przeszkody w jego wybudowaniu. Jeśli komuś przeszkadzało to, że sąsiad z łatwością mógł patrzeć na jego dom czy wręcz zaglądać do niego, to musiał na własną rękę i według własnego uznania przedsięwziąć różnego rodzaju środki ochronne.

Zasadniczo więc do wzniesienia domu wystarczało zachowanie minimalnej odległości między budynkami określonej przez prawo. Zgodnie ze znanymi nam konstytucjami cesarskimi wynosiła ona $10^{29}$ (ok. $3 \mathrm{~m}$ ) lub $12^{30}$ (ok. 3,60 m) stóp, a w traktacie Juliana również 10 stóp. Istniały od tego jednak istotne wyjątki w sytuacji, gdy przewidziana była szczególnego rodzaju ochrona widoku na różnego rodzaju krajobrazy lub obiekty. Zagadnieniu temu poświęcone były konstytucje cesarskie, a w traktacie paragrafy 52-56 stanowiące jego drugą część i znacznie różniące się w stylu od pozostałych regulacji zawartych w tekście. Fragment ten jest pod względem językowym zdecydowanie bardziej kwiecisty, ozdobny i skomplikowany gramatycznie (np. stosowany jest w nim pluralis maiestatis, który nie pojawia się nigdzie indziej), co pozostaje w silnym kontraście z prostym językiem Juliana. Zasadniczo przyjmuje się więc, iż nie mamy tu do czynienia z oryginalnym tworem Juliana, a powtórzeniem czy skompilowaniem przez niego konstytucji cesarskich ${ }^{31}$.

Faktycznie prawnej ochrony widoku dotyczyło kilka aktów prawnych pochodzących z kancelarii cesarskiej, przy czym wszystkie, które są nam znane poświęcone były wyłącznie widokowi na morze (pro-

${ }^{29}$ C. $8,10,11$.

${ }^{30}$ C. $8,10,12,2$.

${ }^{31}$ H. J. Scheltema The nomoi of Julian of Ascalon, [w:] Symbolae Symbolae ad jus et historiam antiquitatis pertinentes ad J.-C. Van Oven dedicatae, M. DAVID, B.A. VAN Groningen, E.M. Mejers, Leiden 1946, s. 352. 
spectus maris). Najstarszym z nich, znanym nam bezpośrednio, jest konstytucja cesarza Zenona - C. 8, 10, 12. Miała ona na celu potwierdzenie i dokładniejsze określenie, a nawet poprawienie prawa wydanego wcześniej przez cesarza Leona (457-74), również dotyczącego ochrony widoku. Kolejne akty w tym zakresie wydał Justynian. Nowela 63 z 538 r. n.e. była odpowiedzią na nieuczciwe działania zmierzające do obejście prawa Zenona i tego samego zagadnienia dotyczyła także kolejna nowela - Nowela 165 wydana najprawdopodobniej między 535 a 540 r. n.e. ${ }^{32}$.

Przedmiotem zainteresowania jurystów rzymskich była także ochrona innych widoków, np. tekst Papiniana ${ }^{33}$, który nie jest znany nam z Digestów a jedynie z traktatu Juliana, mówił o widoku na góry. Znaczenie widoku, przede wszystkim na morze, potwierdzają również klasyczne teksty literackie np. Cycerona ${ }^{34}$, Wergiliusza ${ }^{35}$ czy Seneki ${ }^{36}$.

Jeśli chodzi o traktat Juliana to zawarte w nim regulacje z zakresu widoku są obszerniejsze i bardziej szczegółowe niż w znanych nam konstytucjach cesarskich. Zaczynają się one od dosyć długiego wstępu (§ 52), w którym mowa jest o tym, że wzrok jest najbardziej rozwiniętym ze zmysłów. Znajduje się tutaj ponadto wskazanie, iż prawne regulacje dotyczące widoku są niejasne czy źle interpretowane w związku z czym potrzebne jest ustalenia jasnych kryteriów ochrony widoku, bo w przeciwnym razie wznoszenie domów, miast i wsi mogłoby stać się całkowicie niemożliwe. Zgodnie z tymi postulatami Julian wyróżnia cztery rodzaje widoków podlegających szczególnej ochronie. Były

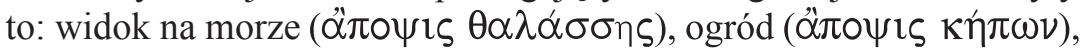

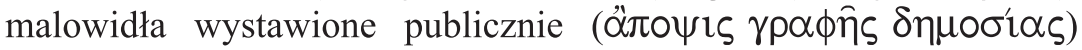

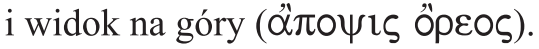

W przypadku widoku na morze ochronie podlegał tylko widok bez-

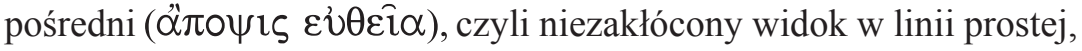

\footnotetext{
32 Tamże, s. 354; C. SAliou, op. cit., s. 238.

${ }^{3}$ Lib. 3 Quaest.

${ }^{34}$ Cic., Ep. ad Familiares, 7,1,11.

35 Verg., Eneida, 2, 223-224.

${ }^{36}$ Sen., ad Lucilium, 89,21.
} 


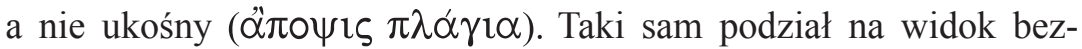
pośredni i ukośny znajdujemy w konstytucji cesarza Zenona i z niej został on wyraźnie przejęty ${ }^{37}$. Ochronę na widok ukośny rozszerzył dopiero Justynian w drodze Noweli 165 . W obu przypadkach o tym, z jakim widokiem mieliśmy do czynienia decydowała pozycja ciała. Widok bezpośredni był to więc taki, gdzie stojąc lub siedząc można było bez problemu widzieć interesującą rzecz, bez wyginania się, pochylania itp ${ }^{38}$. (fig. 1). U Zenona znajdujemy jednak doprecyzowanie tej reguły, które nie pojawia się u Juliana. Mianowicie widok bezpośredni nie podlega ochronie wszędzie, a dokładniej w miejscach, w których był on bezużyteczny, czyli w pomieszczeniach użytkowych i przejściowych, takich jak latryna, schody, kuchnia czy korytarz ${ }^{39}$.

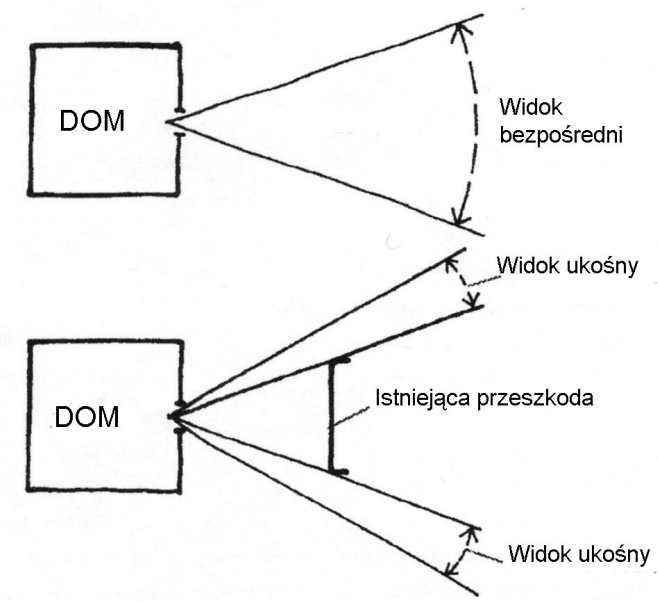

Fig. 1. Schematyczne przedstawienie widoku bezpośredniego i ukośnego (za B.S. НАкIM, Julian of Ascalon treatise of construction and design rules from sixth-century Palestine, «Journal of the Society of Architectural Historians» 60.1/2001, fig. 8).
${ }^{37}$ C. $8,10,12,2 \mathrm{a}$.
${ }^{38}$ C. SAliou, op. cit., s. 241.
39 C. $8,10,12,4 a$. 
W konstytucjach cesarskich dotyczących ochrony widoku morze traktowane było jako całości, natomiast u Juliana znajdujemy rozróżnienie na dwa rodzaje krajobrazu morskiego. Ochronie podlegał widok na port, jeśli taki istniał, a w jego braku na zacumowane statki albo po prostu zatokę, a także widok na bliskie morze rozumiane jako linia brzegowa, bo z takiego widoku czerpało się przyjemność. Nie dotyczyła ona natomiast widoku na pełne morze. W jego wypadku nie dałoby się bowiem ustalić minimalnej odległości między budynkami dla jego ochrony, gdyż jest one dostrzegalne z bardzo daleka (fig 2).

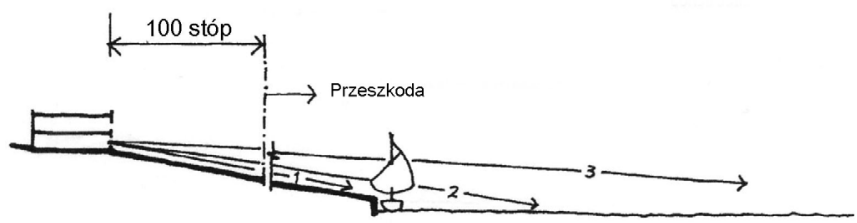

1 - Widok na port lub zatokę

2 - Widok na pobliskie morze

3- Widok na dalekie morze

Fig. 2. Schematyczne przedstawienie różnych rodzajów widoków na morze (za B. S. НАКIM, Julian of Ascalon treatise of construction and design rules from sixth-century Palestine, «Journal of the Society of Architectural Historians» 60.1/2001, fig. 9).

Zarówno konstytucje jak i traktat przewidywały w zakresie ochrony widoku na morze servitus ne prospectui officiatur (servitus prospectus), czyli służebność widoku polegającą na tym, że sąsiad w żaden sposób nie mógł ograniczać widoku z budynku władnącego ${ }^{40} \mathrm{i}$ w tym celu jego dom musiał być oddalony aż o 100 stóp (ok. $30 \mathrm{~m})^{41}$. Taki dystans przewidziany był także w traktacie Juliana (§ 56). Służebność widoku tak ukształtowana nie była ustanawiana $\mathrm{w}$ drodze porozumienia stron, ale wynikała bezpośrednio z mocy prawa ${ }^{42}$. Nie wyklucza-

\footnotetext{
${ }^{40}$ D. $8,2,3$; D. $8,2,12$; D. $8,2,15$; D. $39,1,5$ pr.

${ }^{41}$ C. $8,10,12,2$.

${ }^{42}$ C. SAliou, op. cit., s. 243.
} 
ło to jednak możliwości zawarcia między zainteresowanymi stronami porozumienia, w drodze którgo dopuszczalne było zrzeczenie się jej i wzniesienie budynku bez zachowania wymaganego prawem odległości ${ }^{43}$. Możliwość taka uregulowana była tylko w konstytucji, natomiast brak o niej wzmianki u Juliana.

Taki sam dystans 100 stóp przewidziany był w traktacie Juliana tak-

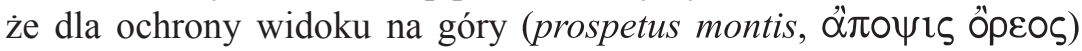
(§ 56), który nie pojawia się nigdy w znanych nam konstytucjach cesarskich. Jak wynika to jednak wprost z traktatu poruszał to zagadnienie Papinian w 3 księdze Quaestiones. Według architekta z Askalonu widok ten był równie urokliwy jak na morze, a podobne należy chronić w podobny sposób. Najprawdopodobniej także ta regulacja zawarta w traktacie bazowała na jakiejś konstytucji, której niestety nie znamy. Można powiedzieć o niej jedynie tyle, że została wydana po konstytucji cesarza Zenona, do której nawiązuje wskazując na dystans konieczny do zachowania ${ }^{44}$.

W traktacie przewidziana była także ochrona widoku na ogród (prospectus hortorum, § 53). Polegała ona na tym, że właściciel domu mającego widok na ogród mógł żądać, żeby nowa konstrukcja znajdowała się w odległości co najmniej 50 stóp (ok. $15 \mathrm{~m}$ ), tak aby nie ograniczała go. Tego rodzaju ochrony nie znajdujemy w żadnej znanej nam konstytucji. Wręcz przeciwnie w konstytucji cesarza Zenona jest mowa o tym, że byłoby niesłuszne obciążenie działki budowlanej taką służebnością ${ }^{45}$. Na tej podstawie można przypuszczać, że kwestia ta musiała być uregulowana gdzieś wcześniej, ale nowy cesarz nie zgadzał się z takimi przepisami.

Taka sama odległość jak w przypadku ogrodów tj. 50 stóp była przewidziana $\mathrm{w}$ traktacie także dla ochrony kolejnego rodzaju wido-

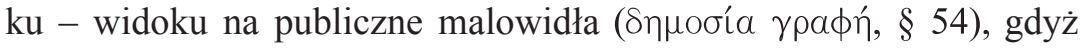
przy takim dystansie przedstawione sceny nie były już rozpoznawalne. Dodatkowym warunkiem ochrony było tutaj rozumienie tematy-

\footnotetext{
43 C. $8,10,12,4 b$.

${ }^{44}$ H.J. Scheltema, op. cit., s. 354-5.

${ }^{45}$ C. $8,10,12,2 \mathrm{a}$.
} 
ki malowideł przez osoby mające na nie widok. Zamieszczenie tego rodzaju regulacji wskazuje na popularność malowideł przedstawiających sceny historyczne i mitologiczne w Askalonie i innych miastach Palestyny w VI w. n.e., co poświadczone jest także przez źródła literackie. Dla przykładu Libaniusz wspominana o człowieku wystawiającym swój portret w miejscu publicznym ${ }^{46}$ i o obrazie znajdującym się na dziedzińcu kurii w Antiochii ${ }^{47}$.

W związku z tym, że w traktacie występuje nie tylko ochrona widoku na morze, ale także na góry, ogród i malowidła, które nie pojawiają się w znanych nam konstytucjach, Julian najprawdopodobniej bazował w tym zakresie na jakiś innych aktach prawnych, które w inny sposób nie zostały nam przekazane. Nie wiadomo kiedy i kto mógł je wydać. Zajmujący się tym zagadnieniem Scheltema ${ }^{48}$ sugeruje, że przynajmniej jeśli chodzi o regulacje odnośnie widoku na ogród miało to miejsce za Basilicusa lub Illusa, uzurpatorów za czasów Zenona. Taka interpretacja dosyć dobrze thumaczyłaby niechęć widoczną w konstytucji C. $8,10,12$. do tego rodzaju służebności. Natomiast konstytucja poświęcona ochronie widoku na góry musiała być wydana już po konstytucji cesarza Zenona, do której nawiązuje.

Z kwestią ochrony zarówno światła jak i widoku ściśle związana jest także typologia okien. Od rodzaju otworu i jego funkcji zależała bowiem wymagana prawem odległość między budynkami czy wysokość, na której miały być one umieszczane. Najbardziej ogólnym greckim terminem na określenie okien jest $\theta u p i ́ \varsigma^{49}$. Zarówno w konstytucji cesarza Zenona, jak i u Juliana znajdujemy ich podstawowe

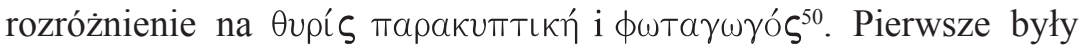
oknami panoramicznymi służącymi do wyglądania (prospectus) i wychylania się przez nie, drugie jedynie dostarczającymi światło i po-

${ }^{46}$ Liban., Or. 42,43.

47 Liban., Prog. 12,2,1.

${ }^{48}$ H. J. Scheltema, op. cit., s. 354.

49 G. Husson, Oikia. Le vocabulaire de la maison privée en Égypte d'après les papyrus grecs, Paris 1983, s. 109-18.

${ }^{50}$ C. $8,10,12,3-3 b$; Julian $-\S 26$. 
wietrze. Wyraźnie wskazują na to ich nazwy. Pierwsza wywodzi się

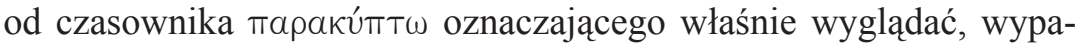
trywać czy wychylać się, natomiast $\phi \omega \tau a \gamma \omega \gamma o ́ s$ znaczy tyle co dający światło. Prawo wyraźnie określało kiedy jaki typ mógł być wybijany w ścianach domu.

Zgodnie z konstytucją cesarza Zenona jeśli zachowany był między budynkami odstęp 12 stóp to właściciel domu mógł podwyższyć go według upodobania i wybić okna do patrzenia ${ }^{51}$. Natomiast jeśli istniejący już od dawna budynek był wzniesiony w taki sposób, że nie był oddalony o wymagany dystans 12 stóp, to nie można było go podwyższyć, ani wybić w nim okien, o ile nie był zachowany odstęp 10 stóp. W takim przypadku zakazane było jednak wybijanie okien panoramicznych. Dopuszczalne było natomiast wykonanie okien doświetlających, przy czym musiały być one umieszczone na wysokości 6 stóp (ok. 1,80 m-1,77 m według stopy rzymskiej i 1,87 m według stopy bizantyńskiej) od podłogi. Zakazane było stosowanie tzw. fałszywej (wysokiej) podłogii ${ }^{52}$ - tzn. wybijanie okna na wysokości 6 stóp, ale nie od poziomu podłogi pomieszczenia a zewnętrznej ściany, co powodowało iż okno służyło praktycznie do patrzenia i naruszało prywatność sąsiadów.

Bardzo podobne regulacje zawiera traktat Juliana, w którym użyte są dokładnie takie same terminy na określenie okien jak w konstytucji. Generalna zasada odnośnie wybijania okien była podobna do tej przedstawionej przez Zenona i zawarta była w paragrafie dotyczącym odległości między budynkami:

$\S 16$ Trzeba, żeby wznoszący i budujący nowy parterowy budynek w mieście odsunął się od sąsiada lub sąsiadów o 10 stóp i będzie mógł umieścić okna jak tylko chce.

Zasada ta miała zastosowanie także do budynków kilkupoziomowych (§ 21). Zasadniczo więc, gdy zachowana była wymagana od-

\footnotetext{
${ }^{51}$ C. $8,10,12,2$.

${ }^{52}$ C. $8,10,12,3 a, b$.
} 
ległość między budynkami dozwolone było wybijanie okien według uznania (a więc zarówno panoramicznych jak i doświetlających).

Rozróżnienie na dwa typy okien znane Zenonowi znajdujemy natomiast $\mathrm{w}$ innym paragrafie:

$\S 26.1$. Jeśli zaś ślepy mur znajduje się naprzeciw innego muru mającego okna do patrzenia i właściciel ślepego muru chciałby wybić okno doświetlające, będzie mógł to uczynić jeśli będzie znajdowało się ono na wysokości 3 i 1/2 łokcia (ok. 1,75-1,80 m) od podłogi jego domu (fig. 3).

2. Jeśli zaś chciałby wybić okno panoramiczne może to uczynić oddalając się od stojącego naprzeciw domu o 20 stóp. Takie bowiem oddalenie jest odpowiednie, żeby sąsiedzi nie przeszkadzali sobie nawzajem słowami i nie demoralizowali się.

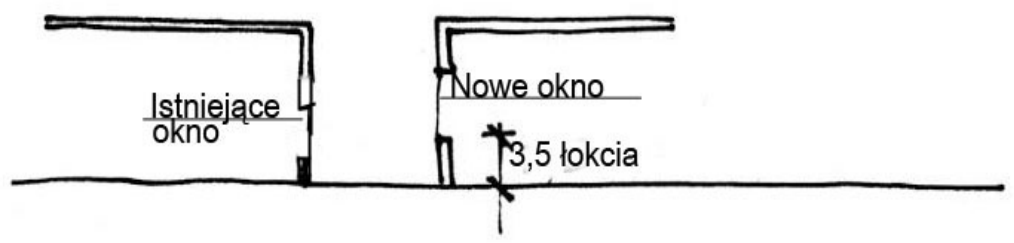

Fig. 3. Wybicie okna doświetlającego (rys. Łukasz Skalec).

Jak widać z powyższych regulacji rozróżnienie pomiędzy typami okien, zarówno w konstytucjach cesarskich jak i u Juliana miało na celu przede wszystkim ochronę prywatności ${ }^{53}$ poprzez zapobieganie podglądaniu przez sąsiadów. W konstytucji Zenona mechanizm tej ochrony był taki sam jak w przypadku widoku. Polegała ona zatem na wydaniu aktu prawnego regulującego odległość między budynkami i wysokość, na której można było wybijać okna. Jednak zawsze mogły być one nieprzestrzegane, jeśli sąsiedzi zawarli w tym przedmiocie stosowne porozumienie ${ }^{54}$. Także $\mathrm{w}$ traktacie Juliana przewidziana

\footnotetext{
53 C. $8,10,12,3 b$.

${ }^{54}$ C. 8,10,12,3b; C. SAliou, op. cit., s. 250.
} 
była ochrona wynikająca wprost $\mathrm{z}$ przepisów, ale $\mathrm{w}$ tym wypadku już bez możliwości ich zmiany w drodze umowy. Mamy tu jednak do czynienia $\mathrm{z}$ wprowadzeniem $\mathrm{w}$ pewnym zakresie większego stopnia ochrony niż w konstytucji. W niej bowiem do wybicia okien panoramicznych wystarczający był zawsze dystans 12 stóp. U Juliana został on zwiększony aż do 20 stóp w przypadku okien do patrzenia wybijanych we wcześniej istniejącej ślepej ścianie. Nie do końca jest dla nas jasne rozróżnienie między budynkami wcześniej już istniejącymi a nowo wznoszonymi, ale był to najprawdopodobniej przejaw jakiejś lokalnej tradycji ${ }^{55}$. Nie jest też wykluczone, że pozostaje to w pewnym związku z wymaganą w pewnych okolicznościach odległością 20 stóp w przypadku zwiększania wysokości budynku, w sytuacji gdy mogło pociagnąć to zmniejszenie wartości sąsiedniego budynku (§ 21.2). Pomimo pewnych różnic reguły zawarte u Juliana i w konstytucji cesarza Zenona są jednak wyrazem tej samej zasady. Możemy tu mieć do czynienia zatem z pośrednim przyjęciem regulacji ${ }^{56}$ albo identycznym ukształtowaniem zasady w tym zakresie w oparciu o doświadczenie. Wysokość 1,80 m wymieniona w obu regulacjach, przy czym z użyciem różnych miar, była bowiem na terenie całego cesarstwa ze względu na średni wzrost ludzi w tamtych czasach wystarczająca, aby przez umieszczone na niej okna nie dało się wyglądać.

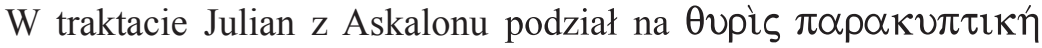
$\imath \phi \omega \tau \alpha \gamma \omega \gamma$ ós uzupełniony był jeszcze o dalsze kategorie, których nie znajdujemy w konstytucji. Pojawia się w nim ponadto ter$\min \tau o \xi \iota \kappa \eta^{57}$ i $\phi \omega \hat{\omega} \varsigma^{58}$. Pierwszy oznacza etymologicznie tucznika czy łuk do strzelania. Drugi znaczy zasadniczo lumen, a więc światło. Najprawdopodobniej oba służył do określania otworu doświetlającego, w przeciwieństwie do $\theta u p i ́ s$, który stosowano do wszystkich okien w ogólności ${ }^{57}$.

W traktacie Juliana z Askalonu możemy wyróżnić więc aż trzy typy okien: okna umieszczone nisko, przez które można wyglądać; wysokie

\footnotetext{
55 C. Saliou, op. cit., s. 250.

56 Tamże, s. 301.

${ }^{57}$ C. Saliou, op. cit., s. 250.
} 
okna doświetlające i okna „strzelnicze”, także doświetlające. Termin $\phi \omega ̄ \varsigma$ mógł obejmować obie ostatnie kategorie, albo odnosić się do kolejnej czwartej, ale nie jesteśmy niestety w stanie tego stwierdzić ${ }^{58}$. Natomiast w konstytucji Zenona znajdujemy jedynie opozycję między oknami panoramicznymi i wysokimi doświetlającymi, co oczywiście nie oznacza, że inne kategorie nie istniały w Konstantynopolu czy innych cześciach Cesarstwa. Świadczy to raczej o braku prawnego znaczenia dalszych podziałów, jako że zawsze dało się je zaklasyfikować do którejś z dwóch głównych grup.

Typy okien, które wyróżnia w swoim traktacie Julian niewątpliwie istniały na terenie Syro-Palestyny. Podobne rozróżnienia znajdujemy bowiem także w świecie biblijnym i talmudycznym. Źródła żydowskie dzieliły okna na „egipskie” i „tyryjskie” stosownie do ich wielkości. Te pierwsze to niewielkie okna, w których nie mieściła się głowa człowie$\mathrm{ka}$, a drugie duże z prostokątną ramą

Także w Liber syro-romanus ${ }^{60}$ wymienione są 3 kategorie okien: pojedyncze okna szerokie na 1 łokieć, okna o podwójnej szerokości i okna mansardowe, wysoko umieszczone. To jaka odległość musiał być zachowana między budynkami zależała od tego czy okna znajdowały się na piętrze czy parterze. W przypadku parteru wynosiła ona od dwóch do czterech stóp w zależności od szerokości okna, natomiast w przypadku piętra nie była przewidziana żadna szczegółowa regulacja.

Ten podział okien na duże okna panoramiczne i mniejsze doświetlające występował na terenie całego cesarstwa, co uzasadniało wprowadzenie prawnego rozróżnienia $\mathrm{w}$ tym zakresie także przez konstytucję cesarską. To przeciwstawienie dwóch typów okien znajdujemy już u Seneki ${ }^{61}$, który pierwszą kategorię określał mianem rimae, drugą $f e-$ nestrae. Pierwsze znajdowały się zazwyczaj na parterze od strony ulicy, drugie wewnątrz wychodząc na dziedziniec czy perystyl. Także

58 Tamże, s. 250 .

59 Y. Hirschfeld, The Palestinian Dwelling in the Roman- Byzantine Period, Jerozolima 1995, s. 255-6, 258.

$60 \S 120$ (FIRA, II, 795).

${ }^{61}$ Sen., ad Lucilium 11,86,8. 
w Pompejach wykorzystywano takie dwa rodzaje okien. W zewnętrznych ścianach wychodzących na ulice były umieszczane wysoko niewielkie, wąskie okna służące właśnie do doświetlania i wentylacji. Natomiast w części domu otwierającej się na dziedziniec, zazwyczaj na piętrze, umieszczano duże okna umożliwiające wyglądanie. Również w Ostii, gdzie okna mają bardzo zróżnicowane wymiary, te wychodzące na ulice zazwyczaj były umieszczone na wyższym poziomie (ponad $2 \mathrm{~m}$ ), niż te wewnętrzne (ok. $130 \mathrm{~cm}$ ), co miało na celu ochronę prywatności mieszkańców ${ }^{62}$. Zasadniczo na większości stanowisk archeologicznych znajdujemy właśnie te dwa typy okien, o których wspomina zarówno Julian jak i Zenon - te niewielkie, wąskie, umieszczone wysoko w ścianach, mające na celu dostarczanie powietrza i światła i drugie - duże zlokalizowane nisko, aby umożliwiać wyglądanie.

Również tradycyjne domy bliskowschodnie miały tylko kilka, zazwyczaj niewielkich okien nad drzwiami albo pod sufitem ${ }^{63}$. Taka ich lokalizacja była w dużej części związana $\mathrm{z}$ ciepłym klimatem panującym w Syro-Palestynie. Umożliwiały one bowiem cyrkulację powietrza, dostarczały światło, a jednocześnie chroniły przed gorącem. Duże okna były wybijane rzadko, zazwyczaj na wyższych piętrach wymagających dodatkowego oświetlenia. Ta „niechęć” do tego typu okien wiązała się zarówno z warunkami klimatycznymi jak i kosztami szyb czy okiennic. Niekiedy okna były umieszczane tylko na wyższych pię$\operatorname{trach}^{64}$ (np. w masywie wapiennym w północnej Syrii ${ }^{65}$ ) i wtedy często znajdowały się na wysokości umożliwiającej na patrzenie z nich.

${ }^{62}$ C. Saliou, op. cit., s. 195, 199.

${ }^{63}$ Y. HiRschFeld, op. cit., s. 249-54, 258.

64 Tamże, s. 257.

${ }^{65}$ J.P. Sodini, G. TATE, Maison d'époque romaine et byzantine (II-VI siecles) $d u$ massif calcaire du Syrie du Nord. Etude typologique, [w:] Actes du colloque Apamee de Syrie. Bilans des recherches archeologique 1973-1979, J. BaLty, Bruxelles 1984, s. 386. 
Dobry przykład okien doświetlających z terenu Bliskiego Wschodu odkryto w Dura Europos. W Domu Skryby ${ }^{66}$ w pomieszczeniu 31 znajdują się trzy otwierające się na ulicę okna umieszczone na wysokości 4,02 m, mające $0,23 \mathrm{~m}$ szerokości i 0,42 wysokości oraz postać lejka zwężającego się ku zewnątrz. Podobnie w budynku chrześcijańskim w tym samym mieście w ścianie północnej pomieszczenia 4 (4A) istniały 3 małe wysoko umieszczone okna mające na celu zapewnienie dostępu powietrza i światła. Takie same znajdowały się w ścianie zachodniej (pomieszczenie 4B). Były to dwa symetrycznie rozmieszczone okna wychodzące na ulice i umieszczone $2,92 \mathrm{~m}$ nad powierzchnią podłogi. Od wewnątrz były one wysokie na $1,09 \mathrm{~m}$, a następnie zmniejszały się ku zewnątrz. Redukcji ulegała także ich szerokość od 0,65 m w dolnej części do $0,35 \mathrm{~m}$ w górnej. Ostatecznie otwory od strony zewnętrznej budynku były szerokie tylko na $0,18 \mathrm{~m}$ i wysokie na $0,49 \mathrm{~m}$. Były one otynkowane i oryginalnie posiadały na zewnętrz drewniane framugi. Wypełnione były szkłem i wyposażone w drewniane okiennice, które można było otwierać z dołu przy pomocy sznura (fig. 3$)^{67}$. Na dziedziniec wychodziły natomiast duże i nisko umieszczone okna.

Bardzo podobne wąskie i wysoko umieszczone okna odkryto w Mampsis w Budynku XII w pomieszczeniu 411 i $412^{68}$, a także w Apamei ${ }^{69}$. Wydaje się, że te niewielkie okna w kształcie lejka można zidentyfikować z występującym się w traktacie Juliana terminem

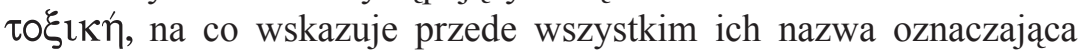
łucznika. Otwory strzelnicze w rzymskich fortyfikacjach przez które

${ }^{66}$ M. I. Rostovtzeff, A. R. Bellinger, C. Hopkins, C. B. Welles, The Excavations at Dura Europos conducted by Yale University and the French Academy of Inscriptions and Letters. Preliminary Report of Sixth Season of Work, October 1932-March 1933, London 1936, s. 273.

${ }^{67}$ C. B. Welles (eds.), The Excavations at Dura-Europos conducted by Yale University and the French Academy of Iscriptions and Letteres, Final report VIII, part II, New York 1967, s. 16-7.

68 A. Negev, The Architecture of Mampsis, Final Report, Volume I: The Middle and Late Nabatean Periods (Quedem 27), Jerusalem 1988, s. 178.

69 J. Balty, La Maison aux Consoles, [w:] Actes du colloque Apamee de Syrie. Bilans des recherches archeologique 1973-1979, J. BALTY, Bruxelles 1984, s. 26. 
łucznicy oddawali swe strzały były bowiem bardzo zbliżone formą do tych okien.

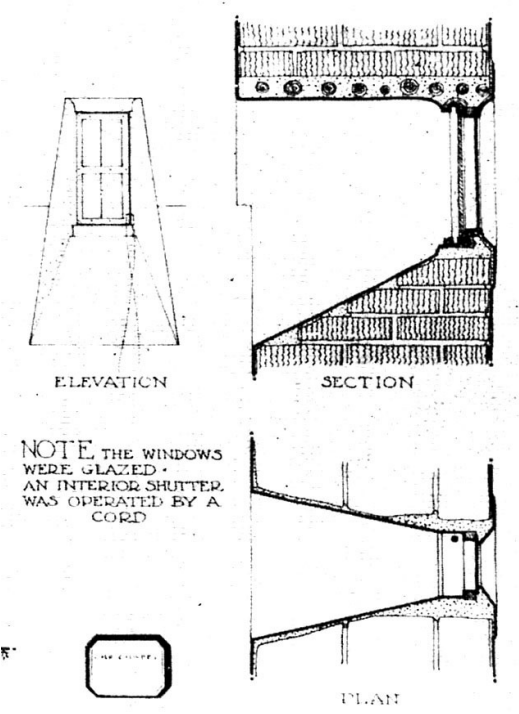

Fig. 3. Dura Europos - wysokie okno w budynku chrześcijańskim (za C.B. Welles (eds.), The Excavations at Dura-Europos conducted by Yale University and the French Academy of Iscriptions and Letteres, Final report VIII, part II, plan VI).

Inny typ wysoko zlokalizowanych okien, ale już nie w postaci zwężających się lejków, lecz niewielkich prostokątnych otworów znajduje się w Umm el-Jimal, np. w domu III czy XVIII, gdzie dodatkowo mamy na piętrze duże okna, przez które niewątpliwie można było wyglądać ${ }^{70}$. Nie wiemy jednak czy można do nich odnieść inny występujący u Juliana termin - $\phi \hat{\omega} \varsigma$, gdyż w tym przypadku nazwa jest zbyt ogólna.

${ }^{70}$ H.C. ButLer, Publications of the Princeton University Archaeological Expedition to Syria 1904-5 and 1909, Leiden 1919, s. 197-202. 
Najprawdopodobniej konstytucja Zenona jak i traktat Juliana, regulując sposób wybijania różnego typu okien, odpowiadały na powszechny w świecie starożytnym problem braku prywatności, który był przedmiotem troski nie tylko w V i VI w. n.e., ale także znacznie później, co poświadczone jest przez Nowelę 113 Leona Mądrego.

Ochrona światła i widoku zajmowała zatem dosyć istotnie miejsce w prawie rzymskim jeśli chodzi o regulowanie stosunków sąsiedzkich. Zagadnień tych dotyczył cały szereg służebności, a niektóre z nich zostały uregulowane w bardziej szczegółowy sposób w konstytucjach cesarskich. Oczywiście nie są nam znane wszystkie istniejące w tym zakresie regulacje, ale pewnych dodatkowych informacji, szczególnie jeśli chodzi o ochronę widoku, dostarcza nam Traktat Juliana $z$ Askalonu. Był on wprawdzie zbiorem praw i zwyczajów obowiązujących w Palestynie, ale można odnaleźć w nim widoczne wpływy czy wręcz bezpośrednie zapożyczenia z konstytucji cesarskich, świadczące o tym, że były wydawane akty poświęcone nie tylko ochronie widoku na morze, ale także na góry, ogród i malowidła publiczne. Bardzo interesującym zagadnieniem z zakresu światła i widoku było także widoczne w obu źródłach rozróżnienie okien na panoramiczne i doświetlające, co odpowiadało dwóm głównym typom okien jakie znajdujemy w domach basenu Morza Śródziemnego i pociagało za sobą odmienne regulacje co do wysokości ich lokalizowania czy odległości między budynkami.

\section{Protection of Light and of View in Roman LaW and Julian of Ascalon's Treatise}

\section{Summary}

Problems of vicinity were a subject of regulations starting from the time of classical Greece, but the most complete text relating to this question is Julian of Ascalon's Treatise, a work written at the end of the $\mathrm{V}$ or during the VI century in Palestine by an architect known by the name of Julian. One of the aspects regulated by this text, as well as, in a similar way, by 
Roman law, was the protection of light and of view. In Roman law light was protected by a series of special servitudes: ius altius tollendi aut non tellendi, ius ne luminibus officiator, servitus luminum and servitus luminis imittendi. An analogy to the latter is also found in the treatise. According to the above sources also the view (prospectus) was protected. In the constitutions of Roman emperors known from the Code of Justinian we find only protection of the sea view, but Julian also regulated protection of the view on mountains, gardens and public paintings and he probably based his regulations on other unknown constitutions. A subject connected with view and light was the typology of windows. In both texts there existed a legally relevant distinction between panoramic windows and ones that served only for lighting, because the first could be made only when certain conditions were met, and the second could be constructed only at a certain height. 